Karel Střelec

Ostravská univerzita

karel.strelec@osu.cz

\title{
Česky psaná literatura jako medium paměti (a zapomnění) Hlučínska*
}

\begin{abstract}
Střelec Karel, Česky psaná literatura jako medium paměti (a zapomnění) Hlučinska, (Czech Written Literature as a Medium of Memory [and Oblivion] of Hlučín Region). "Poznańskie Studia Slawistyczne" 16. Poznań 2019. Publishing House of the Poznań Society for the Advancement of the Arts and Sciences, Adam Mickiewicz University, pp. 257-266. ISSN 2084-3011.

The following paper is based on the concept of literature and mediality of memory (Astrid Erll) which deals with the function of literary texts in creating and maintaining collective memory. Using these methodological incentives, it focuses on the determination and characterization of ways in which Czech literary works co-create and preserve the memory of the $20^{\text {th }}$ century Hlučín Region, as well as, vice versa, the ways involved in suppressing some layers of memory and oblivion. The area described is selected, inter alia, because of its discontinuous and multi-layered memory influenced by geopolitical changes in Central Europe. The study thus provides a more detailed view of how artistic literature, as a medium of collective memory, can function within the phenomena of the so-called abused memory and memory work (Paul Ricœur).
\end{abstract}

KEYwORDS: Czech literature; collective memory; Hlučín Region; $20^{\text {th }}$ century ideologies

\section{1. Úvod}

Jedním ze současných konceptů, které propojují výzkum paměti a literatury, je př́stup nahlížející literární díla jako média paměti; umělecké texty mají v tomto pojetí funkci vytváření a uchovávání individuální či kolektivní paměti, a naopak mohou selekcí či (auto)cenzurou také plnit funkci jejího vymazávání. Literatura se tak podílí na celospolečenském utváření pamětového diskurzu a podstatnou měrou jej formuje, jak připomíná Astrid

* Tato studie je výstupem z projektu SGS01/FF/2018 Vybrané žánrové a subžánrové proměny v součawsné české literatuře II. 
Erllová $(2015,201)$ : „Literatura je médium, které rozhodujícím způsobem spoluovlivňuje kulturní vzpomínání." Tyto procesy přitom mohou hierarchicky probíhat na různých úrovních - od paměti celého civilizačního okruhu (Bible, antické texty) až k paměti národní či subnacionální. Narativní texty se tak spolupodílejí na jevu, který označuje Paul Ricœur pojmem práce paměti (travail de mémoire). Ten vyjadřuje antipod ke zneužívání kolektivní paměti (l'abus de la mémoire), které zahrnuje tři podtypy: pamět' potlačenou, manipulovanou a povinnou (la mémoire empêchée, la mémoire manipulée, la mémoire obligée). Pro všechny je typické ideologické zneužití a negativní společenský efekt (Ricœur, 2000, 82).

Posttraumatické období, ${ }^{1}$ v Evropě ovlivněné dvěma světovými válkami, holokaustem či komunistickými diktaturami, význam literatury jakožto média paměti zvýraznilo a prohloubilo. K tomuto zvýznamnění došlo zejména tam, kde byla pamět' narušena $\mathrm{v}$ největší míře a kde ji poznamenala ztráta přirozené kontinuity - at' už v podobě etnických, národnostních a náboženských čistek, nucených přesunů obyvatelstva, ideologických manipulací nebo cenzury. Mezi jednu z evropských lokalit, jejíž identita je velmi silně ovlivněna řadou zmíněných historických přelomů, zvratů a politických a národnostních proměn, patří Hlučínský region, dnes součást území České republiky. Nevelká oblast, nacházející se v jižním Slezsku, byla v roce 1742 v důsledku válek o rakouské dědictví postoupena Prusku a jeho součástí zůstala až do dvacátých let 20. století. V roce 1920 Hlučínsko na základě Versailleské mírové smlouvy přsšlo pod Československou republiku; exaktní stanovování nové hranice na trojmezí mezi Polskem, Pruskem a Československem však pokračovalo až do roku 1923, kdy byly k Masarykovu státu navíc prripojeny obce Hat' a Píšt'. Mezi lety 1938 a 1945 tvořil region součást nacistického Německa, po ukončení druhé světové války se během poslední geopolitické změny v oblasti Slezska opět vrátil pod Československo. V této souvislosti připomeňme, že na rozdíl od oblasti Sudet na Hlučínsku nedošlo k poválečnému masivnímu odsunu německého obyvatelstva.

${ }^{1} \mathrm{~V}$ této studii se blíže nevěnujeme teoriím traumatu, které humanitní vědy v posledních desetiletích vytvořily a rozpracovaly; připomeňme jen jednu stručnou, avšak všeobecně platnou poznámku k termínu trauma: „Tento pojem má v historii zásadní význam a [...] musí zaujmout místo mezi základními formami historické diskontinuity: jako ,kolektivní traumata“ jsou vnímány závažné události (revoluce, dobytí, porážka)“(Le Goff, 2007, 155). 


\section{Pamět' Hlučínska 20. století v literárních dílech}

Jedno z prvních zachycení paměti 20. století bývalého pruského regionu představuje prozaický svazek Zdeňka Bára Ztracený domov s podtitulem Prózy z černého kraje, vydaný v roce 1938 a v rozšířené podobě v roce 1946. ${ }^{2}$ Kapitola datovaná do 4. února 1920 tematizuje přelomový dějinný bod, oficiální a současně symbolické předání mocenské správy Hlučínska zástupcům Československa. Okolnosti však naznačují, že německá strana nevnímá ztrátu území jako definitivní: „Meine Herrn, odcházíme z této země, této německé země, kde žijí naši drazí Moravci (a to pan baron se bil v prsa), odcházíme, ale všichni se vrátíme, abychom vám vrátili drahou německou svobodu, kterou milujete!!!“ (Bár, 1946, 126). O dvě dekády pozdější inverzní postoupení hlučínského regionu nacistickému Německu se mísí ve vzpomínkách postavy československého vojáka:

Naše oddíly pomalu opouštějí město. Je to strašná cesta, je to tragický návrat, který bolí. Důstojník v čele svého pluku řídil evakuační práce. Důstojník, který kdysi jako mladíček vtáhl s pěchotou do tohoto města. Roku 1920. 4. února. Tak dávno, tak dávno, že už to snad ani pravda není. Jaká to byla tehdy krásná cesta. Ale dnes? [...] Je mu líto tohoto ústupu, ale ví dobře, že vše se děje přesně podle plánu v kázni a pořádku. A podle tvrdého rozkazu. Rozkazu cizích mocností (Bár, 1946, 131).

Absurdita mocenských změn a utrpení však u Bára ústí v již definitivní osvobození republiky v závěru druhé světové války, potrestání viníků minulého traumatu a patetický návrat Hlučínska k vlasti.

${ }^{2}$ Paralelně s česky psanou literaturou se tématu věnují také autoři píšící německy. Mezi nejvýraznější z nich bezpochyby patří Bolatický rodák August Scholtis (1901-1969), jehož dílo prostupuje pamět' Hlučínska jako návratný leitmotiv. Jedná se již o meziválečná díla, jako např. Baba und ihre Kinder (Baba a její děti), Ostwind. Roman der oberschlesischen Katastrophe (Východní vítr. Román hornoslezské katastrofy) nebo Das Eisenwerk (Železárny). Komplexitou pak vyniká poválečný syntetický román Ein Herr aus Bolatitz (Pán z Bolatic), rozsáhlá autobiografie přeložená do češtiny teprve v roce 2008 . Za jeden z mnoha paradoxů dějin 20. století lze považovat skutečnost, že Scholtis, zastánce př́itomnosti německé civilizace v Horním Slezsku, choval obdivný vztah k Petru Bezruči a byl s ním v korespondenčním kontaktu (Paverová, 2008, 6-7). Podrobněji se Scholtisovi a dalším německým autorům spjatým s regionem věnoval autorský kolektiv pod vedením Ireny Šebestové v triptychu monografí Kulturní a literárni život německy mluvícího obyvatelstva na Hlučínsku, Německý literárni svět na Hlučínsku a Po stopách německy psané literatury na Hlučinsku.

Za česky psané pamětové prózy Hlučínska první poloviny 20. století lze považovat také některá díla Frana Směji, zejména romány Potřisněná tvár̆ (1939) a Jidáši (1946). 
Během komunistické epochy se Hlučínsko stává neaktuálním, ve své podstatě nežádoucím námětem ve smyslu Ricœurovy potlačené paměti; přestože velké části německy hovořícího obyvatelstva bylo umožněno v republice zůstat, stát usiloval o asimilaci zdejších tradic a kultury. V rámci širšího regionu je tak v literatuře zdůrazňováno průmyslové Ostravsko, exemplární př́klad socialistické výstavby a nové sociální situace socialistického člověka. ${ }^{3}$ Jistou výjimku v tomto směru tvoří soubor Kraje za Opavicí. Hlučínsko v literatuře, vydaný pod vedením Milana Rusínského v roce 1970. Svazek byl koncipován jako připomínka padesáti let od připojení regionu k Československu a výběrově se zabývá knihami, které jej reflektují.

Je zřetelné, že česká literatura do konce 80 . let 20. století funguje jako médium paměti Hlučínska z perspektivy vítězné (tedy české) strany a posiluje tak obraz homogenní identity. K obratu ve fokalizaci dochází po roce 1989 , kdy se pozornost řady děl šířeji rozprostírá a předkládá zpracování paměti ve více perspektivách bez snahy o monopolizaci pouze jedné z nich. Česká literatura je tak v př́ípadě Hlučínska součástí širšího procesu, kdy jako médium paměti vstupuje do rekonciliace posttraumatické society: „K tomu je zapotřebí otevř́t se pluralitě pamětí a odhalit nepřiznané křivdy. Ricœur pokládá snahu o ,spravedlivou pamět'“ za morální povinnost, kterou dnešní generace dluží minulosti a jež je součástí etiky zodpovědnosti“ (Šubrt, Pfeiferová, 2010, 23). Tematizuje tak i protichůdné perspektivy, nebot', jak upozorn̆uje Wachtel $(1971,309)$, „historie se tak jeví jako racionální jen vítězům, zatímco poražení ji prožívají jako iracionalitu a odcizení.“ Nejnovější literární díla lze tudíž daleko spíše než za média paměti označit za média pamětí, včetně těch, které jsou ve společnosti ohroženy zánikem, zapomněním.

Mezi časté formy zpracování proměn Hlučínska ve 20. století je subžánr rodového románu. Ten ve svých prózách opakovaně aplikuje Anna Malchárková, regionální autorka, která se paměti místa nejhlouběji věnovala v románu Grunt. Autenticitu tohoto díla, stejně jako další autorčiny tvorby, zvýrazňuje práce se zdroji v podobě orálních vzpomínek i písemných pramenů; realistický efekt zprostředkovává až př́iznakově časté užívání toponym či jejich enumerací: „V Bohuslavicích byla nevěsta sice mladá, ale vdova, v Kobeřicích dávali málo věna, v Darkovicích byly

${ }^{3}$ Této problematice se podrobněji věnovala např. Iva Málková (2012, 229-243). 
všechny zadané, ale v Hati, tam se mu jedna zamlouvala“ (Malchárková, 2011, 40). Z jinak striktní chronologické narace vybočuje pouze úvodní kapitola, zasazená do přítomnosti - v čase se vyvíjející kontinuita rodu je však v př́běhu opakovaně narušovaná ,,velkými dějinami“, historickými zlomy a traumaty. Aktualizaci námětu představuje motiv rodového prokletí, dávné tragické smrti, zaviněné jednou z ústředních postav, stejně jako motiv zakořeněné nenávisti mezi lidmi. Román tak nezjednodušuje otázku viny na prvek externí - přirozenou součástí traumatické paměti minulého století je i jednání běžných občanů. Proměny společnosti vnášejí podmínky k pomstě, kariérnímu růstu bez etických ohledů či peněžnímu obohacení se na úkor perzekvovaných postav.

Kompozice dalšího z románů pamětí Hlučínska, knihy Třešňovou aleji Evy Tvrdé, vytváří vědomí paměti dvojí - zatímco první část je fikční narací původních obyvatel, druhá je věnována nově přišedším volyňským Čechům, dosidlujícím území po druhé světové válce. Tyto dvě skupiny lidí jsou symbolicky kondenzovány do hlavních ženských postav, Edeltraud a Ludmily. Obě linie i dívky propojuje motiv domu, místa, které je materiálním pamět'ovým nosičem, jak připomíná Jan Assmann (2001, 39): „Pamět' potřebuje místa, má tendenci přejít do prostoru.“ Na rozdíl od prózy Malchárkové, Tvrdá nepojednává o apriorních mravních selháních; ta jsou naopak (a jen okrajově) vyobrazena jako důsledek tíživých a traumatizujících okolností. Rovněž šíře záběru autorky je užší, její dvě protagonistky a jejich rodiny jsou přesto vnímatelné jako typizované postavy reflektující události 20. století na Hlučínsku.

Silný akcent staví román na dialektický vztah mezi pamětí a zapomněním. Zatímco sama próza usiluje o zachycení paměti místa; tematizuje však i opačný pól, tedy její vynucenou či přirozenou ztrátu. V metonymické rovině ji mimo jiné ztělesňuje stará kamenická značka na zápraží rodného domu - tam, kde je pro Edeltraud něčím přirozeným a známým, mění se pro Ludmilu v nejasný, smyl nedávající artefakt. Samozřejmost kontinuity, s níž ji první z dívek vnímá, je explicitní: „hladila při tom značku v kamenném schodu. Tahle značka přežije staletí. Nikdo z nich už nebude mezi živými a tahle značka tady pořád bude“ (Tvrdá, 2008, 14). Pro nově příchozí oproti tomu představuje Třebom labyrint neznámých významů; sít', jejíž pamět' je neprohlédnutelná, nepoznatelná a s níž se v důsledku nemohou identifikovat: „Tady křičel tajemstvím každý hrnek v kuchyni, 
každý schod, každá kamenná kostka v dláždění na dvoře. Minulost všech z okolí byla neznámá, stejně jako současnost i budoucnost“" (Tvrdá, 2008, 90).

V neposlední řadě je poukazem na ohrožení paměti i sama třešňová alej z titulu knihy. V Edeltraudiných vzpomínkách dominantní a okouzlující místo, stromořadí mezi Třebomí a sousedními Sudicemi, které se - ve finální části románu již stárnoucí - žena vydává najít. Dojde však ke zjištění, že mýtus tohoto loci amoeni je falešný, v polích spojujících obě obce rostou jen nevzhledné jabloně a trnky. Síla a trvání individuální paměti jsou radikálně zpochybněny: „Urputně trvala na svých vzpomínkách, ale byly k ničemu. Svět se nedá vrátit zpět. Žádná z jejích vzpomínek nemá pro dnešek hodnotu“ (Tvrdá, 2008, 125). Křehkost individuální (a v přesahu logicky také kolektivní) paměti může vést k zapomnění, které „činí oba cíle - pravdivost a věrnost - obtížněji dosažitelnými“ (Šubrt, Pfeiferová, 2010, 23).

Silnou, a přesto vyššími událostmi dějin stíhanou ženskou postavou je rovněž ústřední hrdinka románu Dědictví. Tvrdá v něm rozvíjí poměrně spletitou sít' epických linií, a to zejména v druhé polovině prózy; námětové schéma využívá obdobných prvků jako pozdější román Třěňnovou alejí. Střet německých a českých zájmů získává v Dědictví personalizovanou podobu v ambivalentním manželství hlavní protagonistky a jejího muže Karla, nejen za něž hledá pravidelně útěchu v kostele v Hati: „Hat'ský kostel stál na kopci a byl z daleka vidět. [...] Usadila se v jedné z lavic a cítila, jak si ji všichni prohlížejí. Měla tady být s Karlem. [...] Začala se modlit a modlila se celou mši. Snad se bůh nebude zlobit, že myslí jen na sebe a na Karla“ (Tvrdá, 2018, 18-19). Jak je evidentní záhy, napětí do vztahu vnáší manželův obdiv k Hitlerově ideologii, živený především jeho bratrem. Právě bratrův patologický charakter vyniká naplno v okamžiku, kdy odmítá Karla zachránit před nástupem na frontu s argumenty o vyšším německém poslání.

Pozornost věnujme ještě samotnému závěru románu, zasazenému do přítomnosti. Kontinuita rodu a jeho pamět' byla v důsledku událostí a traumat minulého století narušena a téměř zničena; o dvě generace mladší Agáta se o ní dozvídá zcela náhle a nečekaně: od rodiny tak, že neměla ani tušení, že nějaká existuje. Přesto se to stalo. Kdyby bra- 
tranec nezemřel a dům neodkázal jí, zřejmě by se nikdy nedozvěděla, odkud pochází. [...] Agáta tenkrát poprvé vyslechla podivnou rodinnou historii. Děda u wehrmachtu, babička zarytá antikomunistka, otec odseknutý od svých kořenů (Tvrdá, 2018, 136).

Do života již dospělé ženy tak toto rozkrytí rodinné paměti vnáší novou otázku o vlastních kořenech a původu. Při návštěvě zděděného domu v Darkovicích však pocituje z minulosti tíhu a bázeň - archetypální truhlu nalezenou na půdě neotevře a nechává tak část své identity a rodové paměti upadnout v zapomnění.

Pamět' Hlučínska je rovněž námětem dvou knih Petra Čichoně básnické sbírky Pruské balady a prózy Slezský román. Obě díla se po uvedení na trh setkala s rozporuplnými kritickými ohlasy, které zejména Slezskému románu vyčítaly př́íklon $\mathrm{k}$ nacistické ideologii a její apologetiku. ${ }^{4}$ Lze však konstatovat, že tyto reakce svědčí o nepřesné interpretaci motivu nostalgie, který Čichoňovy texty prostupuje. Ten je silný zejména v Pruských baladách, dvojjazyčné česko-německé knize členěné do tří oddílů: V zasněženém Slezsku, Árijská láska a V Sanssouci. ${ }^{5}$ Státní mocí potlačená pamět' pruské identity prosvítá ve sbírce již od úvodních veršů, a to i ve formě užívání germanismů v české verzi - zmiňována jsou toponyma jako Altreich, Oberschleisen a další. Český prvek naopak reprezentuje útlak, potlačení identity: „V zasněženém Slezsku, jež Krista nezná, / zasněžené Slezsko svatý Václav pálí“ (Čichoň, 2006, 10). Oproti rupturám a zvratům, obsaženým v paměti Horního Slezska, je kontinuálním, nadčasovým rámcem prŕŕroda: „Odra teče jednoduše, / jako když letí vrána. / Do vody pláče hned zrána / landecká Venuše, // modlí se za cikána, / který kouří u řeky. / Odra teče tiše / v šachtě, jež je zbourána, // Odra, slzy landecké Venuše" (Čichoň, 2006, 22). Motiv Odry funguje také jako pojítko s dalšími

${ }^{4}$ Mediálně nejvýrazněji proti knize vystoupila s článkem Probouzení hnědé krve literární kritička Eva Klíčová v týdeníku Respekt, kde ji označila za „románový debut, který je zcela otevřeně zamilovaný do nacistické estetiky i ideologie“ (Klíčová, 2011). Tuto tezi vzápětí odmítl Jiří Peňás v Lidových novinách, který upozornil na logiku výběru dané látky: „Hlučínské či slezsko-německé téma je legitimní a je na Čichoňově románu právě tím nejzajímavějším“ (Peňás, 2011). Problematika údajné ideologické inklinace díla rezonovala rovněž v řadě rozhovorů s autorem. Polemická a místy ostrá debata (mediální, akademická, ale i celospolečenská) také poukázala na význam, který má literární text ve vztahu k národní paměti.

${ }^{5}$ Již tato dvojjazyčnost díla poukazuje na pamět' Hlučínska - evokuje dřivější běžné, paralelní užívání obou jazyků v regionu. 
řekami, delimitujícími germánské území a obsaženými v dalších básních (Rýn, Spréva).

Až fatalistické pojetí „ztraceného ráje“ graduje v nezvratný osud kraje - v trauma, jež je odsunuto do zapomnění. Právě při hledání paměti poražených hledá sbírka limity, jejichž překročení u recipientů a společnosti v širším měřítku vyvolá paralely mezi pruskou identitou Hlučínska a nacistickou ideologií. I pro německou společnost, jak také připomíná Langenohl $(2015,281)$, je konec druhé světové války dvojsmyslným okamžikem dějin: „Je známo, jak problematické pro mnoho Němců bylo identifikovat se s procesem vyrovnávání se $\mathrm{s}$ dědictvím autoritářského režimu, především kvůli nedostatečnému odporu ze strany německého obyvatelstva. Nesčetné debaty na téma, zda květen 1945 symbolizuje v Německu osvobození, nebo porážku, to jen dokazují.“ Tato, z všeobecného diskurzu vytěsněná pamět', je v Pruských baladách podtržena i elegickým vyzněním veršů:

Chtěl bych vše vrátit, ale chtěl bych, aby to bylo jako kdysi, / nad měsícem musí přece ještě jeden měsíc svítit, / nad sluncem by mělo ještě jedno slunce svítit! // Ale nemohu si vzpomenout, i kdybych měl se, / že jsem se s Tebou líbal na Unter den Linden, / naše láska je rozbitá a jiná! / Nemohu si vzpomenout, a i kdybych si vzpomněl, že po Wilhelmstraße jsem za Tebou přijel, // naše země je rozbitá a postavená jinak! (Čichoň, 2006, 54).

V Čichoňově prozaickém zpracování tématu je vrstevnatost paměti Hlučínska zvýrazněna kompozičním rámcem; tři časové roviny jsou rozvrženy do prrítomnosti, 90. let a doby druhé světové války. Spojitost s Pruskými baladami je kromě prostorové souvislosti ukotvena postavou Hitlerova architekta Hanse Kammlera; pátrání ústřední postavy, doktoranda Martina, je vystavěno paralelně s líčením Kammlerova života a osudů během nacistické okupace a krátce po ní. Inspirace reálnou postavou je ve Slezském románu doplněna o fiktivní prvky, které dvě narativní linie propojují. Pamět' a identita regionu je precizně cizelována s ohledem na její výlučnost:

,Shlesien gehört so ein bisschen zu Polen?`Stavbyvedoucí se obrátí ke Kurtovi. [...] Wasserpolacken! [...] Přemýšlí... Na Ostravsku jsou Poláci známí jako pokoutní obchodníci s pašovaným zbožím... Vaserpolaci? Kurt se pokouší vybavit si Poláky, které zná. Žijí především v Bohumíně a v Jablunkově. Jsou to vlastně Češi, ale mluví polsky. Někteří z nich mají i polské občantsví. [...] Po marném přemýšlení z něj vypadne strohá odpověd'. ,Najn“ (Čichoň, 2011, 47). 
V neposlední řadě román tematizuje, na rozdíl od dalších námi pojednávaných děl, dobrovolné zapomenutí a vzdání se vědomí minulosti bez vnějšího donucení: „Do svažité ulice vjíždí béžový mercedes paní Nové. Její př́jmení jako by symbolizovalo rozchod této ženy s její vlastní minulostí. Heidla Hoch bývala členkou německého spolku dívek v Ludgerstahlu, ale hned po válce se provdala a její minulost i s rodným jménem zmizely se slávou starého Altreichu“ (Čichoň, 2011, 90). V jiném případě však toto odmítnutí rodové paměti není úplné: „To tě zklamu... Babička po válce odmítá německy mluvit. I když si po večerech čte Liebesromane“ (Čichoň, 2011, 122).

\section{Závěr}

Literatura tematizující minulost Hlučínska je médiem paměti, které se spolupodílí na vytváření a uchovávání kolektivní paměti regionu. Reflektuje kontinuitu i diskontinuální zlomy, které se podepsaly během 20. století na identitě této svébytné lokality; je přitom zřetelné, že zejména díla posledních dvou dekád se zaměřují na vrstevnatost a různorodost této paměti. Zatímco v období první poloviny minulého století je kladen akcent na českou národní pamět' v protikladu k německému živlu, novější próza i poezie pracuje s pamětí a traumaty obou národnostních skupin. At’ už se jedná o zpracování v podobě lyrických básní, rodových románů či postmoderní prózy, pamět’ová díla Hlučínska aktivně vstupují do procesu kulturního vzpomínání a v mnoha rovinách umožňují jakožto médium odvrátit ztrátu kolektivní paměti, a tedy zapomnění.

\section{Literatura}

Bár, Z. (1946). Ztracený domov: prózy z černého kraje. Opava: Iskra.

Čichoň, P. (2006). Pruské balady. Brno: Host.

Čichoň, P. (2011). Slezský román. Brno: Host.

Malchárková, A. (2011). Grunt. Ostrava: Repronis.

Scholtis, A. (2008). Pán z Bolatic. Háj ve Slezsku: Maj-Tiskárna.

Scholtis, A. (1935). Baba a jeji déti. Praha: Sfinx.

Scholtis, A. (1940). Železárny: román. Praha: Fr. Borový. 
Směja, F. (1939). Potřisněná tvář. Moravská Ostrava - Mar. Hory: Iskra.

Směja, F. (1946). Jidáší. Mor. Ostrava-Praha: J. Lukasík.

Tvrdá, E. (2008). Třě̌ñovou alejí. Ostrava: Repronis.

Tvrdá, E. (2018). Dédictví. Ostrava: Littera Silesia.

\section{Prameny}

Assmann, J. (2001). Kultura a pamět’. Praha: Prostor.

Erllová, A. (2015). Literárněvědné koncepty paměti. V: Pamět’ a trauma pohledem humanitních věd. Ed. A. Kratochvil. Praha: Ústav pro českou literaturu AV ČR, s. 190-206.

Klíčová, E. (2011). Probouzeni hnědé krve. „Respekt“. https://www.respekt.cz/tydenik/2011/46/probouzeni-hnede-krve. 13.11.2011.

Langenohl, A. (2015). Pamět'v postautoritářských společnostech. V: Pamět' a trauma pohledem humanitnich věd. Ed. A. Kratochvil. Praha: Ústav pro českou literaturu AV ČR, s. 280-291.

Le Goff, J. (2007). Pamět' a dějiny. Praha: Argo.

Málková, I. (2012). Industriálni Ostravsko jako literárni krajina. V: Krajina. Vytváření prostoru v literatuře a výtvarném uméní. Eds. J. Malura, M. Tomášek. Ostrava: Filozofická fakulta Ostravské univerzity v Ostravě, s. 229-243.

Paverová, I. (2008). August Scholtis (předmluva). V: Pán z Bolatic. A. Scholtis. Háj ve Slezsku: Maj-Tiskárna, s. 5-7.

Peňás, J. (2011). Vyšel tu nacistický román? Kdepak, jen slabý. „Lidovky.cz“. https:// www.lidovky.cz/vysel-tu-nacisticky-roman-099-/kultura.aspx?c=A111125_152 018 ln kultura btt. 27.11.2011.

Ricœur, P. (2000). La mémoire, l'histoire, l'oubli. Paris: Seuil.

Šebestová, I. (ed.) (2017). Po stopách německy psané literatury na Hlučínsku. Hlučín: Muzeum Hlučínska.

Šebestová, I. (ed.) (2014). Kulturní a literární život německy mluvícího obyvatelstva na Hlučínsku. Hlučín: Muzeum Hlučínska.

Šebestová, I. (ed.) (2016). Německý literární svět na Hlučínsku. Hlučín: Muzeum Hlučínska.

Šubrt, J., Pfeiferová, Š. (2010). Kolektivní pamět' jako předmět historicko-sociologického bádání. „Historická sociologie“, č. 1, s. 9-29.

Wachtel, N. (1971). La vision des vaincus, les Indiens du Pérou devant la conquête espagnole. Paris: Gallimard. 